\title{
Critical comparison of the impact of biochar and wood ash on soil organic matter cycling and grassland productivity
}

Jones, David; Hill, Paul; Chadwick, David

\section{Soil Biology and Biochemistry}

DOI:

10.1016/j.soilbio.2017.03.012

Published: 01/07/2017

Peer reviewed version

Cyswllt i'r cyhoeddiad / Link to publication

Dyfyniad o'r fersiwn a gyhoeddwyd / Citation for published version (APA):

Jones, D., Hill, P., \& Chadwick, D. (2017). Critical comparison of the impact of biochar and wood ash on soil organic matter cycling and grassland productivity. Soil Biology and Biochemistry, 110, 134-142. https://doi.org/10.1016/j.soilbio.2017.03.012

\footnotetext{
Hawliau Cyffredinol / General rights

Copyright and moral rights for the publications made accessible in the public portal are retained by the authors and/or other copyright owners and it is a condition of accessing publications that users recognise and abide by the legal requirements associated with these rights.

- Users may download and print one copy of any publication from the public portal for the purpose of private study or research.

- You may not further distribute the material or use it for any profit-making activity or commercial gain

- You may freely distribute the URL identifying the publication in the public portal ?
}

Take down policy

If you believe that this document breaches copyright please contact us providing details, and we will remove access to the work immediately and investigate your claim. 
1 Critical comparison of the impact of biochar and wood ash on soil organic matter cycling and

2 grassland productivity

3 Eleanor Y. Reed*, David R. Chadwick, Paul W. Hill, Davey L. Jones

4 School of Environment, Natural Resources \& Geography, Bangor University, Bangor,

5 Gwynedd, LL57 2UW, UK

6

7

$8 \quad$ *Corresponding author: Eleanor Y. Reed

9 Email: ereed@wardell-armstrong.com

10 Tel: +44(0)1912320943

11 Eleanor Y. Reed previously published under the name: Eleanor Y. Swain. Present address:

12 Wardell Armstrong LLP, 11 Waterloo Square, Newcastle upon Tyne, NE1 4DP, United 13 Kingdom

14

15

16

17

18

19

20

21

22

23 
Wood represents the single most important source of renewable energy worldwide and depending on the mechanism of energy production can lead to the production of by-products with vastly different properties (i.e. wood ash (WA) from incineration and biochar (BC) from pyrolysis). These are typically applied to land, however, a critical comparison of their impact on soil quality and carbon $(\mathrm{C})$ cycling is lacking. To address this, we generated biochar $\left(450^{\circ} \mathrm{C}\right)$ and wood ash $\left(870^{\circ} \mathrm{C}\right)$ from the same mixed hardwood feedstock and added it to an agricultural grassland at comparable rates under both laboratory and field conditions (10 $\mathrm{t} \mathrm{ha}^{-1}$ and $571 \mathrm{~kg}$ $\mathrm{ha}^{-1}$ for $\mathrm{BC}$ and WA, respectively). We hypothesized that alkaline, nutrient-rich wood ash would stimulate microbial activity, resulting in the loss of soil organic matter (SOM), while biochar which is recalcitrant to microbial attack would promote the stabilization of native SOM. The effects on the soil microbial community and soil $\mathrm{C}$ and $\mathrm{N}$ cycling were determined over 1 year. Overall, biochar promoted soil quality by enhancing nutrient availability (P and $\mathrm{K})$, moisture retention and increasing soil $\mathrm{C}$ content. However, it was also associated with an increase in below-ground $\mathrm{CO}_{2}$ loss. As plant productivity was unaffected and laboratory incubations of biochar with ${ }^{14} \mathrm{C}$-labeled SOM showed no indication of priming, we deduce that this $\mathrm{CO}_{2}$ originates from the biochar itself. This is supported by the lack of effect of biochar on soil N cycling, microbial biomass and community structure. Wood ash had almost no effect on either soil quality or vegetation quality (yield and foliar nutrient content) under field conditions but did induce negative SOM priming under both laboratory and field conditions. We conclude that when applied at field-relevant rates, neither amendment had a detrimental effect on native SOM cycling. While wood ash promotes the retention of native SOM, biochar may be a better strategy for enhancing SOM levels because of its intrinsic recalcitrant character, however, this needs to be offset against the reduced amount of energy derived from pyrolysis in comparison to incineration. 


\section{Introduction}

Wood is the most important global source of renewable energy, providing about $6 \%$ of the global total primary energy supply (FAO, 2016). During energy production, the pyrolysis or complete incineration of wood biomass results in the formation of biochar and ash respectively. These by-products can be applied to agricultural soils as an organic amendment and/or a liming agent to improve soil quality (Demeyer et al., 2001; Lehmann, 2007; Atkinson et al., 2010). However, while wood ash has been used for many decades as a soil improver, legislation still prevents the application of biochar to land in many countries (Van Laer et al., 2015). This is due to the unintended risks and uncertainties surrounding its potential short- and long-term impacts on agricultural productivity and environmental health (Marks et al., 2015; Subedi et al., 2015). In addition, political decisions to adopt renewable energy technologies are frequently made after a complete cradle-to-grave life cycle assessment (LCA) has been undertaken (Evans et al., 2009). While pyrolysis yields less energy and has greater by-product transport and processing costs than incineration, biochar application to agricultural land may lead to a greater enhancement of soil quality and native soil organic matter (SOM) storage (Lehmann and Joseph, 2009; Marculescu, 2012). Currently, however, no studies have been undertaken to directly compare the impact of biochar and wood ash within the same soil system, particularly under field conditions.

Current evidence on the impact of biochar and wood ash on soil functioning remains contradictory with both positive and negative agronomic and environmental responses being reported (Lychuk et al., 2014). These responses include changes in yields (Chan et al., 2007; Bierderman and Harpole, 2012), altered C and nutrient dynamics (Singh et al., 2010; Gul and Whalen, 2016), changes in soil greenhouse gas emissions (Bass et al., 2016) and reductions in the efficacy of pesticides and herbicides (Yu et al., 2009; Jones et al., 2011a). The beneficial properties of biochar have largely been attributed to its high surface area, surface charge density and cation exchange capacity, intrinsic nutrient load (e.g. NPK and cations), low bulk density, 
high porosity and high pH (Atkinson et al., 2010; Dai et al., 2016; Jones et al., 2012). However, losses of $\mathrm{C}, \mathrm{N}$, sulfur (S) as well as acidic functional groups in biochar with increasing pyrolysis temperature are unavoidable. In addition, biochar (particularly derived from manure, biosolids or waste) increases the risk of heavy metal contamination as such elements become concentrated with increasing pyrolysis temperature (Cantrell et al., 2012; Lucchini et al., 2014; Subedi et al., 2016).

In contrast, the beneficial properties of wood ash have largely been linked to its high alkalinity and nutrient load (Ca, Mg, P and K) (Demeyer et al., 2001). However, it is likely that some of these properties will be short lived (e.g. nutrient and $\mathrm{HCO}_{3}{ }^{-}$release), and that over time, the effect of these soil amendments will decrease as a consequence of both the movement of the soil amendments in the soil profile, and the ongoing biogeochemical interactions with the amendments (Quilliam et al., 2013ab).

In terms of LCA, one of the most important factors to be considered is whether biochar or wood ash promotes the storage or release of $\mathrm{C}$ contained within native SOM. These changes can be mediated through shifts in the size and activity of the soil microbial community, by altering soil physical properties or by altering crop growth. In the case of biochar, many studies have observed an immediate short-term elevation in $\mathrm{CO}_{2}$ evolution after biochar amendment (Smith et al., 2010; Zimmerman, 2010, 2011). This release of $\mathrm{CO}_{2}$ may result from the biotic consumption or abiotic release of some of the biochar components (Cross and Sohi, 2011; Jones et al., 2011b), and/or the enhanced mineralization of native SOM (positive priming; Kuzyakov et al., 2009; Jones et al., 2011b; Luo et al., 2011). However, studies have revealed both positive and negative priming effects of biochar on native SOM, depending on the characteristics of the biochar, soil type and the time after biochar application (Wardle et al., 2008; Cross and Sohi, 2011; Jones et al., 2011b; Biederman and Harpole, 2012; Ventura et al., 2014). In contrast, no studies exist on the potential priming effect of SOM by wood ash, especially under field conditions in agricultural soils (Merino et al., 2016). 
The aim of this study was therefore to: (i) directly compare the effect of biochar and wood ash on soil quality and crop productivity; and (ii) ascertain whether biochar or wood ash induces SOM priming under both laboratory and field conditions. We hypothesized that alkaline, nutrient-rich wood ash would stimulate microbial activity and induce positive priming and the loss of SOM while biochar, which is resistant to microbial attack, would promote stabilization of native SOM.

\section{Materials and methods}

\subsection{Biochar and wood ash production}

Biochar was made by pyrolyzing $\left(450^{\circ} \mathrm{C}, 48 \mathrm{~h}\right)$ the mechanically chipped trunks and large branches of Fraxinus excelsior L., Fagus sylvatica L. and Quercus robur L. (BioRegional HomeGrown $^{\circledR}$; BioRegional Charcoal Company Ltd, Wallington, Surrey, UK). Complete incineration of $10 \mathrm{t}$ of this wood-based biochar at $870{ }^{\circ} \mathrm{C}$, yielded $571 \mathrm{~kg}$ of wood ash. Biochar was milled to a homogenous powder, and both materials were sieved to $<5 \mathrm{~mm}$ before use. Physical and chemical properties of the biochar and wood ash soil amendments are given in Table 1. Total elemental analysis was performed with a S2 Picofox TXRF Spectrometer (Bruker Corp., Billerica, MA). Specific surface area was determined by the BET (BrunauerEmmett-Teller) $\mathrm{N}_{2}$ adsorption method using a TriStar 3020 analyzer (Micromeritics Inc., Norcross, GA). Cation exchange capacity (CEC) was determined according to the method of Sumner and Miller (1996).

\subsection{Field site}

The field trial was established in September 2014 at Abergwyngregyn, Wales $\left(53^{\circ} 14^{\prime} 20^{\prime} \mathrm{N}, 4^{\circ} 00^{\prime} 47^{\prime} \mathrm{W}\right)$ on a flat field previously used for grass silage production (Fig. S1). No herbicide sprays were used to desiccate the old sward prior to trial establishment. The soil is a Eutric Cambisol sandy clay loam derived from freely-draining, mixed Ordovician glacial 
till deposits. The experiment was designed as a randomized block with three treatments (biochar, wood ash and control) and four replicate $3 \mathrm{~m} \times 3 \mathrm{~m}$ plots. Biochar (BC) was spread by hand on the soil surface at a rate of $10 \mathrm{t} \mathrm{ha}^{-1}$, and wood ash (WA) at a rate of $571 \mathrm{~kg} \mathrm{ha}^{-1}$ (the quantity of ash produced by burning $10 \mathrm{t}$ of biochar). All plots were then watered to minimize dust losses. The treatments were subsequently mechanically harrowed into the topsoil (0-10 $\mathrm{cm}$ Ah horizon) to ensure uniform mixing. The rate of wood ash amendment is within the national limit for application to agricultural land ( $1 \mathrm{tha}^{-1} \mathrm{y}^{-1}$; HMSO, 2014) while the rate of biochar application was chosen based on likely rates of application by farmers.

In autumn 2014, a 2 year Italian Ryegrass (Lolium mutiflorum L.) silage ley was sown (Donke tet $(50 \%)$, Gemini tetraploid (25\%), Menbel $(25 \%)$ ) at a seed rate of $0.034 \mathrm{t} \mathrm{ha}^{-1}$. Following national policy (see on-line Supplementary Information), the plots received no fertilizer or herbicide treatment throughout the experiment. Weather data recorded by an onsite automated station for the experimental period is presented in Table S1.

\subsection{Soil quality analysis}

Soil samples were taken fortnightly for the first four months, then monthly for eight months. Five random topsoil samples $(0-10 \mathrm{~cm})$ were removed from each plot using a core sampler, bulked and transported to the laboratory within $2 \mathrm{~h}$ of sampling and stored in gas permeable plastic bags at $4^{\circ} \mathrm{C}$ until required. Within $24 \mathrm{~h}$ of collection, soil samples were sieved to pass $2 \mathrm{~mm}$, extracted and stored in the freezer at $-20^{\circ} \mathrm{C}$. All extractions followed the same protocol: soil samples of $5 \mathrm{~g}$ were shaken for $30 \mathrm{~min}$ at $200 \mathrm{rev} \mathrm{min}^{-1} \mathrm{using}$ either $1 \mathrm{M} \mathrm{KCl}$, $0.5 \mathrm{M} \mathrm{K}_{2} \mathrm{SO}_{4}$ or $0.5 \mathrm{M}$ acetic acid $(1: 5 \mathrm{w} / \mathrm{v})$, centrifuged $(3220 \mathrm{~g})$ for $10 \mathrm{~min}$ and filtered (Whatman No. 42), the samples were subsequently stored for analysis at $-20^{\circ} \mathrm{C}$ in polypropylene vials (MISR/SAC, 1985; Jones and Willett, 2006).

Soil $\mathrm{pH}$ and electrical conductivity (EC) were determined on field-moist soil $(1: 2 \mathrm{w} / \mathrm{v}$ soil-to-distilled water). Soil moisture content (MC) was determined by drying at $105^{\circ} \mathrm{C}(24 \mathrm{~h})$ 
and SOM determined by loss-on-ignition at $500^{\circ} \mathrm{C}(16 \mathrm{~h})$, both wt $\%$. Exchangeable $\mathrm{K}$ and plant-available $\mathrm{P}$ were extracted using $0.5 \mathrm{M}$ acetic acid $(1: 5 \mathrm{w} / \mathrm{v})$ and the filtered extracts analyzed using a Model 410 Flame photometer (Sherwood Scientific, Cambridge, UK) for K and colorimetrically for P (Murphy and Riley, 1962). Dissolved organic carbon (DOC) and extractable organic nitrogen (EON) were extracted using $0.5 \mathrm{M} \mathrm{K}_{2} \mathrm{SO}_{4}(1: 5 \mathrm{w} / \mathrm{v})$ and determined using a Multi N/C 2100S (Analytik-Jena AG, Jena, Germany). Total C and N were analyzed on dry samples using a TruSpec ${ }^{\circledR} \mathrm{CN}$ analyzer (Leco Corp., St Joseph, MI). Available $\mathrm{N}$ was extracted using $1 \mathrm{M} \mathrm{KCl}(1: 5 \mathrm{w} / \mathrm{v})$ and colorimetric analysis of $\mathrm{NO}_{3}{ }^{-}$using the vanadate method of Miranda et al. (2001) and $\mathrm{NH}_{4}{ }^{+}$using the Na-salicylate-hypochlorite procedure of Mulvaney (1996). Free amino acids were extracted using $1 \mathrm{M} \mathrm{KCl}(1: 5 \mathrm{w} / \mathrm{v})$ and determined using a Varian Cary Eclipse Fluorescence Spectrophotometer (Jones et al., 2002). Potential net $\mathrm{N}$ mineralization was estimated on a monthly basis using the anaerobic incubation method of Keeney (1982).

Microbial phospholipid fatty acids (PLFAs) tests were carried out to investigate the shift in microbial community structure during the duration of the field trial as described in BarteltRyser et al. (2005). Individual PLFA concentrations were determined by GC-MS and taxonomic groups ascribed using the Sherlock ${ }^{\circledR}$ PLFA Method and Tools Package (PLFAD1) by Microbial ID Inc. (Newark, DE, USA). The results for each individual fatty acid were expressed as a percentage of the total amount of fatty acids (mol\%) found in a given sample.

\subsection{Plant-soil respiratory $\mathrm{CO}_{2}$ flux in the field}

$\mathrm{CO}_{2}$ flux measurements were carried out in-situ, using an automated LI-8150 multiplexer automated $\mathrm{CO}_{2}$ flux system (LI-COR Inc., Lincoln, NE). Dark chambers (LI-COR LI-8100-104), $20.3 \mathrm{~cm}$ in diameter, were delimited by polyvinyl chloride (PVC) collars that were permanently inserted $c a .5 \mathrm{~cm}$ into the soil from the start of the field trial, with one chamber in each plot. Soil $\mathrm{CO}_{2}$ flux was measured continuously every $2 \mathrm{~h}$ in each plot using 
an automated infrared gas analyzer (LI-COR LI-8100) connected to the multiplexer system. A soil temperature thermistor (LI-COR 8150-203) was connected to each chamber to record soil temperature in each plot. All calibration and system testing was undertaken according to LICOR (2014). In addition, the chambers contained a vent for pressure equilibration between the closed chamber and the atmosphere (McDermitt et al., 2005). The soil $\mathrm{CO}_{2}$ flux, soil temperature and relative humidity $(\mathrm{RH})$ of the air within the chambers, were measured for each plot for 14 consecutive days in April 2015 to study diurnal variation in soils amended with biochar and wood ash. These measurements were made in the growing season to capture the combined response of both the plants and soil, however, we acknowledge that this may not reflect the $\mathrm{CO}_{2}$ flux immediately after field application of the amendments.

\section{5. ${ }^{14} \mathrm{C}$-SOM mineralization in the laboratory}

A short-term (50 d) incubation experiment was carried out with $10 \mathrm{~mm}$ sieved ${ }^{14} \mathrm{C}$ labelled Eutric Cambisol soil (collected from next to the field experiment; $53^{\circ} 14^{\prime} 21^{\prime \prime} \mathrm{N}$, $4^{\circ} 00^{\prime} 56^{\prime \prime} \mathrm{W}$ ) sampled from $0-10 \mathrm{~cm}$ depth (Ah horizon) with roots and stones removed. The

${ }^{14} \mathrm{C}$-labelled SOM had been labelled 5 years previously with ${ }^{14} \mathrm{C}$-labelled glucose. Briefly, a dilute solution (5 1) of ${ }^{14} \mathrm{C}$-uniformly labelled glucose $\left(<1 \mathrm{nM} ; 12.8 \mathrm{MBq} \mathrm{1}{ }^{-1}\right.$; PerkinElmer, UK) was dispensed uniformly across replicate $1 \mathrm{~m}^{2}$ plots. Five years after label incorporation into the plant-soil system the ${ }^{14} \mathrm{C}$ remaining within the soil was considered to contribute to the quasi-stable SOM pool (Farrar et al., 2012).

After $17 \mathrm{~d}$ of pre-incubation $\left(20^{\circ} \mathrm{C}, 50 \%\right.$ water filled pore space) to allow any sampling and sieving effects to subside (Kemmitt et al., 2006), 0.81 plastic flasks (surface area $30 \mathrm{~cm}^{2}$ ) were filled with $168 \mathrm{~g}$ field moist soil (100 g DW). Corresponding directly to the field application rates used above, the soil was amended with either biochar at a rate of $18 \mathrm{mg} \mathrm{g}^{-1}$ soil, wood ash at a rate of $1 \mathrm{mg} \mathrm{g}^{-1}$ soil or left unamended (control). Both treatments had four replicates and the control ran with eight replicates to ensure an accurate baseline. 

a plastic scintillation vial containing $4.0 \mathrm{ml}$ of $1 \mathrm{M} \mathrm{NaOH}$ inside the sealed plastic flask, on top of the soil/treatment mixtures. The $\mathrm{NaOH}$ trap was replaced 14 times at increasing intervals over a $50 \mathrm{~d}$ incubation period. The ${ }^{14} \mathrm{CO}_{2}$ collected as $\mathrm{NaH}^{14} \mathrm{CO}_{3}$ in the $\mathrm{NaOH}$ was measured by liquid scintillation counting in a Wallac 1404 scintillation counter (PerkinElmer Life Sciences, Boston, MA) after mixing with HiSafe 3 scintillation fluid (Fisher Scientific, Loughborough, UK). The initial ${ }^{14} \mathrm{C}$ content (prior to incubation) of the bulk soil was determined after incineration of $0.1 \mathrm{~g}$ of sample within an OX400 Biological Sample Oxidizer (RJ Harvey Instrument Corp., Hillsdale, NJ), with the ${ }^{14} \mathrm{CO}_{2}$ evolved collected in Oxosol scintillation fluid (National Diagnostics Ltd, Hessle, UK) and the ${ }^{14} \mathrm{C}$ content measured by liquid scintillation counting as described above.

The incubation experiment was repeated, replacing the ${ }^{14} \mathrm{C}$-labelled soil with unlabeled soil from an adjacent plot, and labelling the microbial biomass $24 \mathrm{~h}$ before the start of the incubation by adding ${ }^{14} \mathrm{C}$-labelled glucose $(1.2 \mu \mathrm{g} \mathrm{C} \mathrm{g}-1$ DW soil $)$ to each soil to produce an activity similar to that of the first experiment (i.e. $1.03 \mathrm{~Bq} \mathrm{~g}^{-1} \mathrm{DW}$ soil). This level of glucose biomass) effect of the substrates (Blagodatskaya and Kuzyakov, 2008; Kuzyakov, 2010).

\subsection{Plant yield and quality}

The grass sward was cut on three occasions; November 2014, March 2015 and May 2015. At each grass cut, dry weight was determined after oven drying $\left(80^{\circ} \mathrm{C}, 24 \mathrm{~h}\right)$. Foliar mineral nutrient content (total $\mathrm{P}, \mathrm{Ca}, \mathrm{Na}$ and $\mathrm{K}$ ) was determined after dry ashing $\left(500^{\circ} \mathrm{C}, 16 \mathrm{~h}\right)$, solubilization of the ash in $1 \mathrm{M} \mathrm{HCl}$ and determined as described above. Total tissue $\mathrm{C}$ and $\mathrm{N}$ content were determined as described above. 


\subsection{Statistical analysis}

To identify seasonal variations a repeated measures ANOVA was applied in the $\mathrm{R}$ statistical environment (R Development Core Team, 2011), to all soil quality properties. Fixed effects were sample time (time), treatment (tr) and time $\mathrm{x}$ treatment, with block (bl) treated as a random effect. The fixed effects on soil parameters were determined. The analyses were carried out using the aov function and residual normality was assessed using the qqnorm function in R. Where necessary, data were square root transformed or ln transformed to achieve normality. The combined data for year were analyzed first, and where interaction terms were significant, further analyses were conducted at each level of the interacting factor. Differences between significant main effect and interaction means were determined using Tukey's Honest Significant Difference (HSD) tests, based on mixed-effects models using the glht function in the multcomp package of R. Paired T tests were used to test for differences between biochar and wood ash chemical properties.

Principal component analyses (PCA) using the proportion of microbial groups in the soil were performed to compare the structure of the microbial community in the different treatments and the respective initial soil samples were carried out using the PCA function in the FactoMineR package in the R statistical environment. Statistical significance was assigned at the $P<0.05$ level.

\section{Results}

\subsection{Chemical and physical properties of biochar and wood ash}

The biochar displayed a significantly higher bulk density and lower CEC and specific surface area than the wood ash $(P<0.05$; Table 1$)$. Consistent with previous work (Jones and Quilliam, 2014; Lucchini et al., 2014), the EC and pH were significantly higher in the wood ash relative to the biochar $(P<0.05)$. Complete incineration caused $\mathrm{EON}, \mathrm{NO}_{3}{ }^{-}$and free amino 
acids to become significantly more concentrated in the ash relative to the partially combusted biochar $(P<0.05)$, whilst total incineration caused a reduction of total $\mathrm{C}$ and $\mathrm{N}$ and available $\mathrm{P}$ in the wood ash relative to the biochar $(P<0.05$; Table 1).

\subsection{Effect of time and treatment on plant and soil properties}

Overall, there was no significant treatment effect on the growth performance (dry matter yield and plant height) or the cumulative nutrient uptake ( $, P, K, N a$ and $\mathrm{Ca}$ ) of the grass in the first year after the application of either biochar or wood ash ( $P>0.05$; data not shown).

The temporal dynamics of the measured soil quality parameters after biochar or wood ash soil amendment are shown in Figure 1. Statistical analysis revealed that there was one significant time and treatment interaction which showed that when the average soil moisture content (MC) was greater than $20 \%$, the biochar soil amendment displayed a significantly higher MC, however, when the average soil moisture dropped below 20\% (i.e. July 2015), there was no treatment effect.

Biochar and wood ash amendment did not result in a significant change in EC, exchangeable $\mathrm{Na}$, soluble $\mathrm{C}$ and $\mathrm{N}\left(\mathrm{NO}_{3}{ }^{-}, \mathrm{NH}_{4}{ }^{+}\right.$or amino acids) or rates of net $\mathrm{N}$ mineralization $(P>0.05$; Fig. 1, Fig. S2). However, biochar significantly increased total soil C and SOM levels relative to the wood ash and control treatments throughout each sample point of the trial $(P<0.05)$, and over the course of the year displayed increased concentrations of available $\mathrm{P}$ and

$\mathrm{K}$ relative to the control (Fig. 1, Fig. S3). Biochar and wood ash addition increased soil pH $(P<0.001)$ for the duration of the field trial, resulting in soils with a $\mathrm{pH} 0.3$ units higher than the control soil (Fig. 1). 


\subsection{Effect of time and treatment on soil microbial communities}

While time of year significantly affected the size and composition of the soil microbial community, neither biochar or wood ash amendment resulted in an appreciable change in these soil properties (Table 2).

\subsection{Effect of biochar and wood ash addition on soil $\mathrm{CO}_{2}$ loss from the field}

The soil amendment effect on soil $\mathrm{CO}_{2}$ flux, soil temperature and relative humidity, measured seven months after treatment application are shown in Table 3. Treatment had a significant effect on the soil $\mathrm{CO}_{2}$ flux, with the biochar plots resulting in a significantly higher soil $\mathrm{CO}_{2}$ flux than the control treatment, which displayed a significantly higher soil $\mathrm{CO}_{2}$ flux than the wood ash treatment $(P<0.001 ; \mathrm{BC}>\mathrm{C}>\mathrm{WA}$; Table 3$)$. The wood ash and control treatments had an average soil $\mathrm{CO}_{2}$ flux 10.6 and 5.0\% lower than the biochar amended soil, respectively. In all sites, a significant positive correlation was observed between soil $\mathrm{CO}_{2}$ flux and soil temperature $(r=0.770)$.

\subsection{Effect of biochar and wood ash addition on SOM turnover in the laboratory}

The effect of biochar and wood ash on the mineralization of native ${ }^{14} \mathrm{C}-\mathrm{SOM}$ in laboratory incubations is shown in Figure 3a. Overall, biochar displayed no significant priming effect after $50 \mathrm{~d}$, however, wood ash induced a negative priming response $(P<0.0001$; Fig. 3a). The presence of wood ash significantly decreased the mineralization of the ${ }^{14} \mathrm{C}$-labeled native soil by $28 \%$ over the $50 \mathrm{~d}$ incubation period relative to the control. The microbial community was assessed at day 50, which revealed a significantly increased microbial biomass in the biochar mesocosm relative to the control, whereas the wood ash resulted in a decreased microbial biomass relative to the control (Table 4). Biochar stimulated the growth of putative AM fungi and Gram-positive bacteria, whilst suppressing the growth of Eukaryotes, Fungi, 
Anaerobes and Actinobacteria relative to the control and wood ash amended soils. The wood ash treated soils revealed a suppressed growth of putative AM fungi relative to the control.

The effect of biochar and wood ash on microbial biomass turnover is shown in Figure 3b.

Despite an initial rapid rate of ${ }^{14} \mathrm{CO}_{2}$ release from the biochar amended soil in the first $10 \mathrm{~d}$, there was no overall effect of biochar or wood ash on the rate of microbial biomass mineralization over the $50 \mathrm{~d}$ incubation period $(P=0.220)$.

\section{Discussion}

\subsection{Vegetation responses to soil amendments and impacts on C cycling}

Our results suggest that biochar and wood ash applied prior to sward establishment had no significant influence on plant growth or nutritional quality, compared to the non-amended soil. This implies that neither amendment promoted above-ground $\mathrm{C}$ storage or led to greater amounts of $\mathrm{C}$ entering the soil from leaf litter. Although we did not quantify rhizodeposition or root/mycorrhizal turnover in situ, we have no evidence from the soil quality measurements to suggest that these were strongly affected by either amendment.

The lack of growth response is consistent with previously studies using the same woodderived biochar (Jones et al., 2012; Quilliam et al., 2012). Recent meta-analyses of the impact of biochar application on soil concluded, however, that applications of biochar to soil do on average increase crop yields (Jeffery et al., 2011; Biederman and Harpole, 2012; Liu et al., 2013). However, Jeffery et al. (2011) noted that crop responses are variable and dependent on a multitude of factors, including, experimental set-up, soil properties, climatic conditions, biochar properties, application rate and the interaction between biochar and fertilizers. Typically, greatest positive yields arise from biochar applications of $>30 \mathrm{tha}^{-1}$, an application rate much greater than that applied in this study. Although high rates of biochar addition are theoretically possible, the practicalities of obtaining sufficient quantities of biochar for large field areas and the economic costs involved in production, processing and transport are likely 
to prohibit such use on commercial farms. The doses used here are therefore more likely to be representative of actual field use.

The wood ash results did not display the typical plant growth improvements associated with ash addition to soil (Krejsl and Scanlon, 1996; Jones and Quilliam, 2014), however, the dose rates used in this study were considerably lower than many previous studies. Our rates, however, are just below the legal limits for wood ash application to agricultural land and were therefore deemed to be more representative than previous studies. In addition, higher dose rates would likely have resulted in excessive alkalization and heavy metal loading of the soil (Jones and Quilliam, 2014).

\subsection{Soil quality responses to biochar and wood ash amendment and implications for $C$ cycling}

Consistent with previous studies, the incorporation of biochar improved soil moisture retention $(20 \%<\mathrm{MC}<30 \%)$ (Jeffery et al., 2011; Saarnio et al., 2013). However, this effect was not maintained once the soil moisture dropped below 20\%. As the soil used here is freely draining, SOM turnover is most negatively affected when the soil dries out in the summer months. We therefore conclude that the slightly increased storage of water seen in the biochar treatment was unlikely to greatly affect SOM turnover rates or plant productivity.

The addition of liming agents to acidic soils is known to increase $\mathrm{pH}$ and improve soil quality due to increases in nitrification and plant productivity (Kemmitt et al., 2006; Jeffery et al., 2011). The control soil used in this study, however, was close to the optimal pH for grassland production ( $\mathrm{pH}$ 6.2) and neither wood ash and biochar addition raised it excessively, consistent with the application of realistic field doses. Soil $\mathrm{pH}$ is considered a key driver in the regulating microbial community structure and rates of $\mathrm{C}$ cycling (Blagodatskaya and Kuzyakov, 2008; Griffiths et al., 2011), with increases in pH generally enhancing microbial activity. However, we did not observe, any in situ effect of the biochar or wood ash addition on the amount of $\mathrm{C}$ stored in the soil microbial biomass, nor its turnover. The absence of 
biochar effects on soil microbial biomass have previously been documented, and has been attributed to soils already experiencing high rates of SOM mineralization and nitrification prior to treatment (Castaldi et al., 2011; Anders et al., 2013; Ameloot et al., 2014; Watzinger et al., 2014).

There was no significant treatment effect for any of the measured $\mathrm{N}$ parameters (total $\mathrm{N}, \mathrm{EON}, \mathrm{NH}_{4}{ }^{+}, \mathrm{NO}_{3}{ }^{-}$and net mineralization). These results suggest that biochar and wood ash had no appreciable effect on SOM turnover and $\mathrm{N}$ cycling. This is evidenced by the lack of change in crop productivity and foliar $\mathrm{N}$ content, which are highly responsive to $\mathrm{N}$ availability (Campbell et al., 2011). It is also consistent with previous wood biochar studies in soils expressing high rates of nitrification prior to biochar application (DeLuca et al., 2006; Jones et al., 2012). This finding suggests that neither amendment can help offset the use of $\mathrm{N}$ fertilizers (and the embedded $\mathrm{C}$ cost associated with their production) but are also unlikely to influence rates of $\mathrm{N}_{2} \mathrm{O}$ emissions.

\subsection{Soil amendment-induced priming of SOC}

The application of biochar increased the topsoil $\mathrm{C}$ content in the field by approximately $27 \%$ relative to the two other treatments $(0-10 \mathrm{~cm}$ layer $)$. This is consistent with the large amount of $\mathrm{C}$ added in the biochar treatment $\left(8.43 \mathrm{t} \mathrm{C} \mathrm{ha}^{-1}\right)$ relative to that added in the wood ash treatment $\left(0.10 \mathrm{t} \mathrm{C} \mathrm{ha}^{-1}\right)$. Whilst there was evidence of a small but measurable increase in $\mathrm{CO}_{2}$ efflux from the biochar plots in the field, this could be attributable to (i) increased plant respiration, (ii) the biotically-mediated breakdown of the added biochar, (iii) abiotic release of inorganic $\mathrm{C}$ contained in the biochar, or (iv) release of $\mathrm{C}$ from native SOM. As there was no alteration in plant biomass yield we do not favor this explanation. In addition, the abiotic release of $\mathrm{C}$ from biochar occurs quickly after introduction to soil and is not favored (Jones et al., 2011b). Lastly, results from the $50 \mathrm{~d}$ incubation study suggest that biochar causes no 'real' priming of native SOM, nor 'apparent' priming from increased turnover of the soil microbial 
community. All the evidence therefore suggests that the increase in $\mathrm{CO}_{2}$ is due to the progressive breakdown of biochar by microbial processes. This is consistent with Jones et al. (2011b) who showed that the water soluble component of this biochar was highly susceptible to microbial breakdown.

Conversely, both the laboratory and field incubation studies provided strong evidence for the negative priming of native SOM in the presence of wood ash. The reduction observed in the field (ca. 5\%) was less than observed in the laboratory (ca. 28\%), however, the field measurements also include plant-derived respiration and $\mathrm{CO}_{2}$ originating from below the soil layer containing the wood ash. Both of these would effectively dilute the negative priming effect observed in the field. It should be noted that the measurement windows were different between the laboratory and field experiments. The laboratory incubations examined the early impact of wood ash amendments while the field measurements looked at the later effects. The laboratory incubations provided strong evidence that wood ash resulted in a persistent negative impact on SOM turnover, suggesting that the field observations were probably not due to changes in plant growth and metabolism. Further, we clearly show that wood ash has no significant impact on the partitioning of glucose-derived $\mathrm{C}$ within the soil microbial biomass (i.e. substrate $\mathrm{C}$ use efficiency), or the turnover of the biomass itself (Fig. 3). This is consistent with small overall changes in soil microbial community structure determined with PLFAs (Table 4). The exact mechanism for this negative priming therefore remains unknown but appears to be unrelated to macronutrient bioavailability or its heavy metal content which is low (Table 1, Table S2). It could be that the CEC and specific surface area of the wood ash chemically stabilizes SOM, however, this requires further investigation. In addition, in the presence of water, wood ash can recrystallize and form concrete which could physically protect SOM (Aamr-Daya et al., 2008; Illikainen et al., 2014).

As wood ash contains only small amounts of $\mathrm{C}$, its addition to soil only results in a small increase in SOM (ca. +0.4\%). However, its impact on repressing below-ground respiration 
could be much more important. Given that the total below-ground $\mathrm{CO}_{2}$ flux at the field site is $15.1 \mathrm{t} \mathrm{C} \mathrm{ha}^{-1} \mathrm{y}^{-1}$ (J.F. Farrar, unpublished), then based on our estimates, negative priming could account for a net storage of $0.76 \mathrm{t} \mathrm{C} \mathrm{ha}^{-1} \mathrm{y}^{-1}$. Cleary, this is much less than the instantaneous $\mathrm{C}$ benefit derived from biochar even at low dose rates $\left(<10 \mathrm{t} \mathrm{ha}^{-1}\right)$.

\section{Conclusions}

Here we demonstrate that when realistic doses of biochar and wood ash are applied to an inherently fertile grassland soil, both amendments result in no major changes in soil quality or agronomic yield. A key finding was that wood ash repressed native SOM turnover while biochar had no effect. Nevertheless, the retention of native soil organic C associated with wood ash was low in comparison to the amount of $\mathrm{C}$ added in a single dose of biochar. However, this needs to be balanced against the potential greater recovery of energy during the complete incineration of the feedstock material. In addition, wood ash may have further benefits over biochar as it easily pelletized and transported (facilitating land application) and is unlikely to affect the efficacy of herbicides and pesticides applied to the soil. Most previous studies on biochar have looked at its impact in comparison to an unamended control treatments or conventional inorganic fertilizers. This study highlights the need for a greater comparison of biochar to other organic wastes (e.g. compost) and products derived from energy production (e.g. anaerobic digestate, wood ash). Ideally, these comparisons should be performed under field conditions, at representative field application rates and also consider the socioeconomic aspects of farm management.

\section{Acknowledgements}

This work was undertaken using funds provided by the Welsh European Funding Office under the SEREN Programme. We thank Mark Hughes and Llinos Hughes (Bangor University) for assistance with the establishment and maintenance of field plots. We also acknowledge 
Prof. Joann Whalen and two anonymous reviewers for their constructive comments which improved this manuscript.

\section{References}

Ameloot, N., Sleutel, S., Case, S.D.C., Alberti, G., McNamara, N.P., Zavalloni, C., Vervisch, B., Vedove, G. delle, De Neve, S., 2014. C mineralization and microbial activity in four biochar field experiments several years after incorporation. Soil Biology \& Biochemistry 78, 195-203.

Aamr-Daya, E., Langlet, T., Benazzouk, A., Queneudec, M., 2008. Feasibility study of lightweight cement composite containing flax by-product particles: Physico-mechanical properties. Cement \& Concrete Composites 30, 957-963.

Ameloot, N., De Neve, S., Jegajeevagan, K., Yildiz, G., Buchan, D., Funkuin, Y.N., Prins, W., Bouckaert, L., Sleutel, S., 2013. Short-term $\mathrm{CO}_{2}$ and $\mathrm{N}_{2} \mathrm{O}$ emissions and microbial properties of biochar amended sandy loam soils. Soil Biology \& Biochemistry 57, 401410.

Anders, E., Watzinger, A., Rempt, F., Kitzler, B., Wimmer, B., Zehetner, F., Stahr, K., Zechmeister-Boltenstern, S., Soja, G., 2013. Biochar affects the structure rather than the total biomass of microbial communities in temperate soils. Agricultural and Food Science 22, 404-423.

Atkinson, C.J., Fitzgerald, J.D., Hipps, N.A., 2010. Potential mechanisms for achieving agricultural benefits from biochar application to temperate soils: a review. Plant and Soil $337,1-18$.

Bartelt-Ryser, J., Joshi, J., Schmid, B., Brandl, H., Balser, T., 2005, Soil feedbacks of plant diversity on soil microbial communities and subsequent plant growth. Perspectives in Plant Ecology Evolution and Systematics 7, 27-49. 
Bass, A.M., Bird, M.I., Kay, G., Muirhead, B., 2016. Soil properties, greenhouse gas emissions and crop yield under compost, biochar and co-composted biochar in two tropical agronomic systems. Science of the Total Environment 550, 459-470.

Biederman, L.A., Harpole, W.S., 2012. Biochar and its effects on plant productivity and nutrient cycling: a meta-analysis. Global Change Biology Bioenergy 5, 202-214.

Blagodatskaya, E., Kuzyakov, Y., 2008. Mechanisms of real and apparent priming effects and their dependence on soil microbial biomass and community structure: Critical review. Biology and Fertility of Soils 45, 115-131.

Campbell, C. A., Lafond, G.P., Vandenbygaart, A. J., Zentner, R.P., Lemke, R., May, W.E., Holzapfel, C.B., 2011. Effect of crop rotation, fertilizer and tillage management on spring wheat grain yield and $\mathrm{N}$ and $\mathrm{P}$ content in a thin Black Chernozem: A long-term study. Canadian Journal of Soil Science 91, 467-483.

Cantrell, K.B., Hunt, P.G., Uchimiya, M., Novak, J.M., Ro, K.S., 2012. Impact of pyrolysis temperature and manure source on physicochemical characteristics of biochar. Bioresource Techology 107, 419-428.

Castaldi, S., Riondino, M., Baronti, S., Esposito, F.R., Marzaioli, R., Rutigliano, F. A., Vaccari, F.P., Miglietta, F., 2011. Impact of biochar application to a Mediterranean wheat crop on soil microbial activity and greenhouse gas fluxes. Chemosphere 85, 1464-1471.

Chan, K.Y., Van Zwieten, L., Meszaros, I., Downie, A., Joseph, S., 2007. Agronomic values of greenwaste biochar as a soil amendment. Australian Journal of Soil Research 45, 629634.

Cross, A., Sohi, S.P., 2011. The priming potential of biochar products in relation to labile carbon contents and soil organic matter status. Soil Biology \& Biochemistry 43, 21272134. 
Dai, Z., Zhang, X., Tang, C., Muhammad, N., Wua, J., Brookes, P.C., Xu, J., 2017. Potential role of biochars in decreasing soil acidification - A critical review. Science of the Total Environment 581/582, 601-611.

DeLuca, T.H., MacKenzie, M.D., Gundale, M.J., Holben, W.E., 2006. Wildfire-produced charcoal directly influences nitrogen cycling in ponderosa pine forests. Soil Science Society of America Journal 70, 448-453.

Demeyer, A., Voundi Nkana, J., Verloo, M., 2001. Characteristics of wood ash and influence on soil properties and nutrient uptake: an overview. Bioresource Technology 77, 287295.

Evans, A., Strezov, V., Evans, T.J., 2009. Assessment of sustainability indicators for renewable energy technologies. Renewable \& Sustainable Energy Reviews 13, 1082-1088.

FAO, 2016. Wood Energy. Rome, Italy.

Farrar, J., Boddy, E., Hill, P.W., Jones, D.L., 2012. Discrete functional pools of soil organic matter in a UK grassland soil are differentially affected by temperature and priming. Soil Biology \& Biochemistry 49, 52-60.

Griffiths, R., Thomson, B.C., James, P., Bell, T., Bailey, M., Whiteley. A.S., 2011. The bacterial biogeography of British soils. Environmental Microbiology 13, 1642-54.

Gul, S., Whalen, J.K., 2016. Biochemical cycling of nitrogen and phosphorus in biocharamended soils. Soil Biology \& Biochemistry 103, 1-15.

HMSO, 2014. Waste exemption: U10 spreading waste to benefit agricultural land. Her Majesty’s Stationery Office, London, UK.

Illikainen, M., Tanskanen, P., Kinnunen, P., Korkko, M., Peltosaari, O., Wigren, V., Osterbacka, J., Talling, B., Niinimaki, J., 2014. Reactivity and self-hardening of fly ash from the fluidized bed combustion of wood and peat. Fuel 135, 69-75. 
Jeffery, S., Verheijen, F.G.A., van der Velde, M., Bastos, A.C., 2011. A quantitative review of the effects of biochar application to soils on crop productivity using meta-analysis. Agriculture, Ecosystems \& Environment 144, 175-187.

Jones, D.L., Willett, V.B., 2006. Experimental evaluation of methods to quantify dissolved organic nitrogen (DON) and dissolved organic carbon (DOC) in soil. Soil Biology \& Biochemistry 38, 991-999.

Jones, D.L., Owen, A.G., Farrar, J.F., 2002. Simple method to enable the high resolution determination of total free amino acids in soil solutions and soil extracts. Soil Biology \& Biochemistry 34, 1893-1902.

Jones, D.L., Edwards-Jones, G., Murphy, D.V., 2011a. Biochar mediated alterations in herbicide breakdown and leaching in soil. Soil Biology \& Biochemistry 43, 804-813.

Jones, D.L., Murphy, D.V., Khalid, M., Ahmad, W., Edwards-Jones, G., DeLuca, T.H., 2011 b. Short-term biochar-induced increase in soil $\mathrm{CO}_{2}$ release is both biotically and abiotically mediated. Soil Biology \& Biochemistry 43, 1723-1731.

Jones, D.L., Rousk, J., Edwards-Jones, G., DeLuca, T.H., Murphy, D.V., 2012. Biocharmediated changes in soil quality and plant growth in a three year field trial. Soil Biology \& Biochemistry 45, 113-124.

Jones, D.L., Quilliam, R.S., 2014. Metal contaminated biochar and wood ash negatively affect plant growth and soil quality after land application. Journal of Hazardous Materials 276, $362-370$.

Kemmitt, S.J., Wright, D., Goulding, K.W.T., Jones, D.L., 2006. pH regulation of carbon and nitrogen dynamics in two agricultural soils. Soil Biology \& Biochemistry 38, 898-911.

Keeney, D. R., 1982. Nitrogen-availability indexes. In Methods of soil analysis. Part 2. 2nd Ed 711-730. Page, A.L., Miller, R.H., Keeney, R.R. eds. American Society of Agronomy, Madison, WI, USA. 
Krejsl, J.A., Scanlon, T.M., 1996. Evaluation of beneficial use of wood-fired boiler ash on oat and bean growth. Journal of Environmental Quality 25, 950-954.

Kuzyakov, Y., Subbotina, I., Chen, H., Bogomolova, I., Xu, X., 2009. Black carbon decomposition and incorporation into soil microbial biomass estimated by ${ }^{14} \mathrm{C}$ labeling. Soil Biology \& Biochemistry 41, 210-219.

Kuzyakov, Y., 2010. Priming effects: Interactions between living and dead organic matter. Soil Biology \& Biochemistry 42, 1363-1371.

Lehmann, J., 2007. A handful of carbon. Nature 447, 143-144.

Lehmann, J., Joseph, S., 2009. Biochar for Environmental Management: An Introduction. Earthscan, London, UK.

LI-COR (2014) Capturing and processing soil GHG Fluxes using the LI-8100A. Application Note 138. LI-COR Biosciences, Lincoln, NE, USA.

Liu, X.Y., Zhang, A.F., Ji, C.Y., Joseph, S., Bian, R.J., Li, L.Q., Pan, G.X., Paz-Ferreiro, J., 2013. Biochar's effect on crop productivity and the dependence on experimental conditions-a meta-analysis of literature data. Plant and Soil 373, 583-594.

Lucchini, P., Quilliam, R.S., Deluca, T.H., Vamerali, T., Jones, D.L., 2014. Increased bioavailability of metals in two contrasting agricultural soils treated with waste woodderived biochar and ash. Environmental Science and Pollution Research 21, 3230-3240.

Luo, Y., Durenkamp, M., De Nobili, M., Lin, Q., Brookes, P.C., 2011. Short-term soil priming effects and the mineralisation of biochar following its incorporation to soils of different pH. Soil Biology \& Biochemistry 43, 2304-2314.

Lychuk, T.E., Izaurralde, R.C., Hill, R.L., McGill,W.B.,Williams, J.R., 2014. Biochar as a global change adaptation: predicting biochar impacts on crop productivity and soil quality for a tropical soil with the Environmental Policy Integrated Climate (EPIC) model. Mitigation and Adaptation Strategies for Global Change 20, 1437-1458. 
Marculescu, C., 2012. Comparative analysis on waste to energy conversion chains using thermal-chemical processes. Energy Procedia 18, 604-611.

Marks, E.A.N., Alcañiz, J.M., Domene, X., 2014. Unintended effects of biochars on short-term plant growth in a calcareous soil. Plant and Soil 385, 87-105.

McDermitt, D., Xu, L., Gracia, R., Madsen, R., Anderson, D., 2005. On equalizing pressure in a soil respiration chamber with pressure in the ambient air under windy conditions, Geophysical Research Abstracts, 7, 05841.

Merino, A., Omil, B., Fonturbel, M.T., Vega, J.A., Balboa, M.A., 2016. Reclamation of intensively managed soils in temperate regions by addition of wood bottom ash containing charcoal: SOM composition and microbial functional diversity. Applied Soil Ecology 100, 195-206.

Miranda, K.M., Espey, M.G., Wink, D.A., 2001. A rapid, simple spectrophotometric method for simultaneous detection of nitrate and nitrite. Nitric Oxide 5, 62-71.

MISR/SAC, 1985. Advisory soil analysis and interpretation. The Macaulay Institute for Soil Research and Scottish Agricultural Colleges Bulletin 1, 1-13.

Mulvaney, R.L., Sparks, D.L., Page, A.L., Helmke, P.A., Loeppert, R.H., Soltanpour, P.N., Tabatabai, M.A., Johnston, C.T., Sumner, M.E., 1996. Nitrogen - inorganic forms. Methods of soil analysis. Part 3-chemical methods. 1123-1184. Page, A.L., Miller, R. H., and Keeney, R. R. eds. American Society of Agronomy, Madison, WI, USA.

Murphy, J., Riley, J.P., 1962. A modified single solution method for the determination of phosphate in natural waters. Analytica Chimica Acta 27, 31-36.

Quilliam, R.S., Marsden, K.A., Gertler, C., Rousk, J., DeLuca, T.H., Jones, D.L., 2012. Nutrient dynamics, microbial growth and weed emergence in biochar amended soil are influenced by time since application and reapplication rate. Agriculture, Ecosystems \& Environment 158, 192-199. 
Quilliam, R.S., Glanville, H.C., Wade, S.C., Jones, D.L., 2013a. Life in the 'charosphere' Does biochar in agricultural soil provide a significant habitat for microorganisms? Soil Biology \& Biochemistry 65, 287-293.

Quilliam, R.S., DeLuca, T.H., Jones, D.L., 2013b. Biochar application rate reduces root nodulation in clover but increases nitrogenase activity in nodules. Plant and Soil 366, 8392.

R Development Core Team, 2011. R: A language and environment for statistical computing. R Foundation for Statistical Computing, Vienna, Austria.

Saarnio, S., Heimonen, K., Kettunen, R., 2013. Biochar addition indirectly affects $\mathrm{N}_{2} \mathrm{O}$ emissions via soil moisture and plant N uptake. Soil Biology \& Biochemistry 58, 99-106.

Singh, B., Singh, B.P., Cowie, A.L., 2010. Characterisation and evaluation of biochars for their application as a soil amendment. Australian Journal of Soil Research 48, 516-525.

Smith, J.L., Collins, H.P., Bailey, V.L., 2010. The effect of young biochar on soil respiration. Soil Biology \& Biochemistry 42, 2345-2347.

Subedi, R., Kammann, C., Pelissetti, S., Taupe, N., Bertora, C., Monaco, S., Grignani, C., 2015. Does soil amended with biochar and hydrochar reduce ammonia emissions following the application of pig slurry? European Journal of Soil Science 66, 1044-1053.

Subedi, R., Taupe, N., Ikoyi, I., Bertora, C., Zavattaro, L., Schmalenberger, A., Leahy, J.J., Grignani, C., 2016. Chemically and biologically-mediated fertilizing value of manurederived biochar. Science of the Total Environment 550, 924-933.

Sumner, M.E., Miller, W.P., 1996. Cation exchange capacity and exchange coefficients, In Sparks, D.L. (ed.) Methods of Soil Analysis. Part 3. Chemical methods. SSSA Book Series 5, Soil Science Society of America and American Society of Agronomy, Madison, WI, USA. 
van Laer, T., de Smedt, P., Ronsse, F., Ruysschaert, G., Boeckx, P.,Verstraete, W., Buysse, J., Lavrysen, L.J., 2015. Legal constraints and opportunities for biochar: a case analysis of EU law. Global Change Biology Bioenergy 7, 14-24.

Ventura, M., Alberti, G., Viger, M., Jenkins, J.R., Girardin, C., Baronti, S., Zaldei, A., Taylor, G., Rumpel, C., Miglietta, F., Tonon, G., 2014. Biochar mineralization and priming effect on SOM decomposition in two European short rotation coppices. Global Change Biology Bioenergy 7, 1150-1160.

Wardle, D. A, Nilsson, M.-C., Zackrisson, O., 2008. Fire-derived charcoal causes loss of forest humus. Science. 320, 629-629.

Watzinger, A., Feichtmair, S., Kitzler, B., Zehetner, F., Kloss, S., Wimmer, B., ZechmeisterBoltenstern, S., Soja, G., 2014. Soil microbial communities responded to biochar application in temperate soils and slowly metabolized ${ }^{13} \mathrm{C}$-labelled biochar as revealed by ${ }^{13} \mathrm{C}$ PLFA analyses: results from a short-term incubation and pot experiment. European Journal of Soil Science 65, 40-51.

Yu, X.Y., Ying, G.G., Kookana, R.S., 2009. Reduced plant uptake of pesticides with biochar additions to soil. Chemosphere 76, 665-671.

Zimmerman, A.R., 2010. Abiotic and microbial oxidation of laboratory-produced black carbon (biochar). Environmental Science \& Technology 44, 1295-1301.

Zimmerman, A.R., Gao, B., Ahn, M.-Y., 2011. Positive and negative carbon mineralization priming effects among a variety of biochar-amended soils. Soil Biology \& Biochemistry $43,1169-1179$. 


\section{Figure legends}

630 Fig. 1 Influence of soil amendment type, biochar (BC: solid line), wood ash (WA: dashed line)

631 and control (C: gray line) and time since application on soil quality parameters between

632 September 2014 and August 2015. Values are the mean of 4 replicates \pm SEM.

633 Fig. 2 Diurnal variation of soil $\mathrm{CO}_{2}$ flux with soil temperature under the biochar, wood ash and 634 control treatments. Temperature averaged for each cycle $(n=12)$, soil $\mathrm{CO}_{2}$ flux averaged for 635 each block $(n=3)$

636 Fig. 3 Mineralization of (a) ${ }^{14} \mathrm{C}$-labelled native SOM and (b) ${ }^{14} \mathrm{C}$-labelled microbial biomass$637 \mathrm{C}$ in the presence and absence of the soil amendments biochar and wood ash. Experiments were 638 performed in the laboratory. Values represent cumulative means of ${ }^{14} \mathrm{CO}_{2}$ evolution $\pm \mathrm{SEM}(n$ $639=4$ for biochar and wood ash and $n=8$ for control). 